Matrik: Jurnal Manajemen, Teknik Informatika dan Rekayasa Komputer

Vol. 20, No. 1, November 2020, pp. 73 84

ISSN: 2476-9843, accredited by Kemenristekdikti, Decree No: 3/E/KPT/2019

DOI: $10.30812 /$ matrik.v20i1.673

\title{
Implementasi Prototype Model dalam Pengembangan Aplikasi Smart Cleaning Sebagai Pendukung Aplikasi Smart City
}

Siti Sauda, Eka Puji Agustini

Universitas Bina Darma, Indonesia

\section{Article Info}

Article history:

Recived, 11 March 2020

Revised, 5 August 2020

Accepted, 8 August 2020

\section{Kata Kunci:}

Prototype

Aplikasi

Smart Cleaning

Sampah

Smart City

\begin{abstract}
ABSTRAK
Sampah merupakan masalah sebagai besar kota yang ada di Indonesia. Kota Palembang merupakan salah satu kota yang ada di Indonesia yang sangat serius mengurusi maasalah sampah. Usaha yang dilakukan pemerintah Kota Palembang dapat dinyatakan berhasil yang dibuktikan dari Piala Adipura yang didapatkan. Namun keberhasilan tersebut masih memiliki sedikit permasalahan yaitu sering terjadinya penumpukan sampah pada bank sampah yang ada, selain itu juga terdapat penumpukan sampah yang daerah tertentu yang disebabkan tidak disiplinnya masyarakat dalam membuang sampah. Untuk itu di dalam penelitian ini bertujuan untuk memberikan solusi berupa partisipasi masyarakat dalam memberikan pengaduan terkait dengan masalah sampah tersebut. Proses pelaporan yang ditawarkan dalam penelitian ini yaitu berupa aplikasi mobile dan web yang dikhususkan untuk memberi pengaduan penumpuka sampah dengan nama Smart Cleaning. Proses pengembangan digunakan metode prototype. Metode ini memiliki kelebihan yaitu melibatkan pengguna dalam proses pengembangannya sehingga akurasi aplikasi yang hasilkan tergolong tinggi. Hasil dari penelitian ini berupa aplikasi smart cleaning yang memiliki akses pengguna masyarakat, administrator dan petugas. Masing-masing pengguna memiliki akses dan fitur tersendiri yang dapat memproses pengaduan masyarakat terkait penumpukan sampah
\end{abstract}

\section{ABSTRACT}

Garbage is a problem in many cities in Indonesia. Palembang City is one of the cities in Indonesia that is very serious about dealing with waste problems. The effort made by the Palembang City government can be declared successful, as evidenced by the Adipura Cup that was obtained. However, this success still has a few problems, namely the frequent accumulation of garbage in existing waste banks; besides that, there is also a buildup of garbage in certain areas due to the indiscipline of the community in disposing of garbage. For this reason, this research has the objective of providing a solution in the form of community participation in providing complaints related to the waste problem. The reporting process offered in this study is in the form of a mobile application that is devoted to making complaints of garbage collectors by the name of smart cleaning. The prototype method is used in the development process. This method has the advantage of involving the user in the development process so that the accuracy of the resulting application is relatively high. The results of this study are in the form of smart cleaning applications that have access to community users, administrators, and officers. Each user has access and features that can process public complaints related to waste collection.

This is an open access article under the CC BY-SA license.

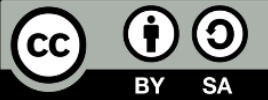

\section{Penulis Korespondensi:}

Siti Sauda,

Program Studi Teknik Informatika, Universitas Bina Darma.

Email: siti_sauda@binadarma.ac.id 


\section{PENDAHULUAN}

Perkembangan teknologi saat ini berkembang dengan cepat. Teknologi berperan penting dalam berbagai kehidupan manusia. Salah satu yang berkembang cepat adalah teknologi berupa aplikasi yang ada pada smartphone. Perkembangan smartphone telah mengalami kemajuan yang sangat cepat. Banyak perubahan yang terjadi dalam kehidupan masyarakat. Mengubah gaya hidup manusia menjadi serba mudah dan praktis. Penggunaan smartphone sudah semakin banyak digunakan dikalangan masyarakat [1]. Masyarakat dapat memanfaatkan smartphone untuk berbagai kebutuhan termasuk sehari hari, seperti akses layanan pemerintah atau kebutuhan pribadi lainnya.

Pada dunia pemerintahan penggunaan teknologi informasi khususnya aplikasi saat ini telah banyak digunakan. Kondisi tersebut dapat dilihat dari berbagai aplikasi yang disediakan diantarnaya (1) Aplikasi Qlue, aplikasi ini digunakan oleh masyarakat untuk memberikan laporan terkait dengan permasalahan kota, selain itu juga aplikasi ini dapat digunakan untuk berbagi informasi [2]]; (2) Aplikasi e-lapor, aplikasi ini merupakan aplikasi yang menggunakan teknologi sosial media untuk menampung keluhan dari masyarakat berkaitan dengan layanan air bersih [3]]; (3) Aplikasi mCity, aplikasi ini meruapak aplikasi yang digunakan untuk memberikan informasi berkaitan dengan pariwisata seperti hotel, kuliner dan objek wisata [4]; (4) Aplikasi Tanggerang Live, aplikasi ini adalah aplikasi integrasi layanan publik yang ada di Kabupaten Tanggerang [5] . Melihat kondisi tersebut maka dapat diketahui bahwa penggunaan aplikasi menjadi tulang punggung pemerintah dalam memberikan layanan kepada masyarakat baik tingkat provinsi maupun kabupaten/kota.

Dinas Lingkungan Hidup dan Kebersihan Kota Palembang merupakan salah satu dinas dalam jajaran pemerintah Kota Palembang. Dinas Lingkungan Hidup dan Kebersihan mempunyai tugas utama untuk menjaga kebersihan dan keindahan kota. Salah satu cara yang dilakukan oleh pemerintah kota untuk melestarikan lingkungan dan keindahannya yaitu dengan melakukan pengambilan sampah secara rutin, sehingga mencegah terjadinya penyakit, bebas dari polusi udara, lingkungan menjadi sejuk dan terhindar dari banjir. Namun upaya tersebut masih kurang maksimal, kondisi tersebut dapat dilihat dari seringnya terjadi penumpukkan sampah disebabkan banyaknya sampah atau terlewati oleh petugas. Kondisi tersebut tentunya menyebabkan aroma yang tidak sedap dan membawa dampak pada kesehatan di lingkungan. Masalah sampah sebenarnya terjadi disetiap kota yang ada di Indonesia, diantaranya adalah di Kota Gorontalo. Di dalam sebuah kajian dikatakan pentingnya mengatasi masalah sampah ini melalui berbagai cara, diantaranya adalah melibatkan masyarakat untuk berpartisipai melalui aplikasi []. Untuk itu permasalahan tersebut tentunya tidak dapat dipandang remeh mengingat Kota Palembang merupakan salah satu kota yang menerima piala adipura sebagai bukti kota yang memiliki nilai kebersihan yang baik.

Dari kondisi tersebut tentunya pemerintah Kota Palembang melalui Dinas Kebersihan dan Lingkungan Hidup harus membuat mekanisme pengaduan yang dapat dengan mudah diakses oleh masyarakat. Cara yang paling memungkinkan yaitu dengan memanfaatkan teknologi informasi berupa aplikasi mobile yang dapat diakses melalui smartphone. Upaya tersebut tentunya sebagai bentuk untuk menciptakan keadaan lingkungan yang bersih dan sehat di Kota Palembang. Untuk itu di dalam penelitian ini bertujuan untuk melakukan pengembagnan aplikasi berbasis mobile dan web yang akan diberi nama smart cleaning sebagai wujud dukungan aplikasi smart city. Sebagaimana diketahui bahwa smart city bertujuan untuk meningkatkan layanan kepada masyarakat menggunakan teknologi informasi termasuk di dalamnya adalah berkatian dengan sampah [7]. Di dalam aplikasi ini akan dibuat mekanisme pengaduan masyarakat berkaitan dengan pelaporan sampah dan dapat di akses langsung oleh petugas kebersihan. Dengan demikian pekerjaan untuk mengatasi penumpukan sampah dapat dipermudah dan dapat mendukung kinerja petugas kebersihan dalam pengambilan sampah.

Untuk mendapat aplikasi smart cleaning yang sesuai kebutuhan pengguna dan dapat diselesaikan dengan tepat maka dalam proses pengembangan digunakan metode pengembangan prototype. Metode prototype memiliki tahapan proses pengembangan yaitu pengumpulan kebutuhan, dilanjutkan dengan pembuatan perancangan, pembuatan prototype aplikasi, evaluasi hasil prototype, memperbaiki prototype aplikasi sampai dengan prototype dianggap sempurna []․ Penggunaan metode prototype sendiri disebabkan metode ini memiliki mekanisme komunikasi yang baik antara pengembang dan pelanggan karena mengedepankan komunikasi dua arah [9]]. Dengan demikian proses pengembangan akan menjadi lebih mudah dan cepat karena banyaknya informasi yangi dimiliki [10]. Selain itu juga metode prototype mampu melakukan proses pengembangan singkat yang disebabkan karena keterlibatan pelanggan secara terus menerus [11]. 


\section{METODE PENELITIAN}

Untuk menyelesaikan penelitian Implementasi Prototype Model Dalam Pengembangan Aplikasi Smart Cleaning Sebagai Pendukung Aplikasi Smart City maka metode yang digunakan dapat dijelaskan sebagai berikut:

\subsection{Metode Penelitian}

Metode penelitian yang saya gunakan dalam penelitian ini yaitu metode action research. Action research yaitu penelitian yang berpusat pada tindakan. Empowering adalah peneliti yang turun langsung ke sebuah daerah penelitian karena tidak bisa di survei. Penelitian action research (tindakan) adalah penelitian yang bersifat kualitatif maupun kuantitatif. Penelitian action research dapat mengatasi suatu masalah di saat yang bersmaan dengan tujuan perbaikan atau partisipasi [12]. Penelitian action research ini merupakan sebuah metode yang didasarkan pada tindakan masyarakat yang seringkali dilakukan pada suatu tempat yang luas, seperti rumah sakit, pabrik, sekolah dan lain sebagainya.

\subsection{Metode Pengembangan}

Dalam pengembangan aplikasi smart cleaining ini menggunakan prototype model. Prototype model adalah salah satu metode pengembangan perangkat lunak yang banyak digunakan, dengan metode prototype ini pengembang dan pelanggan dapat saling berinteraksi selama proses pembuatan aplikasi. Sering kali terjadi pelanggan hanya mendefinisikan secara umum apa yang dibutuhkan, pemrosesan dan data apa saja yang dibutuhkan [13]. Dalam pengembangan aplikasi harus memperhatikan tahapan dalam metode pengembangan, metode prototype memiliki proses pengembangan seperti pada Gambar 1 [14].

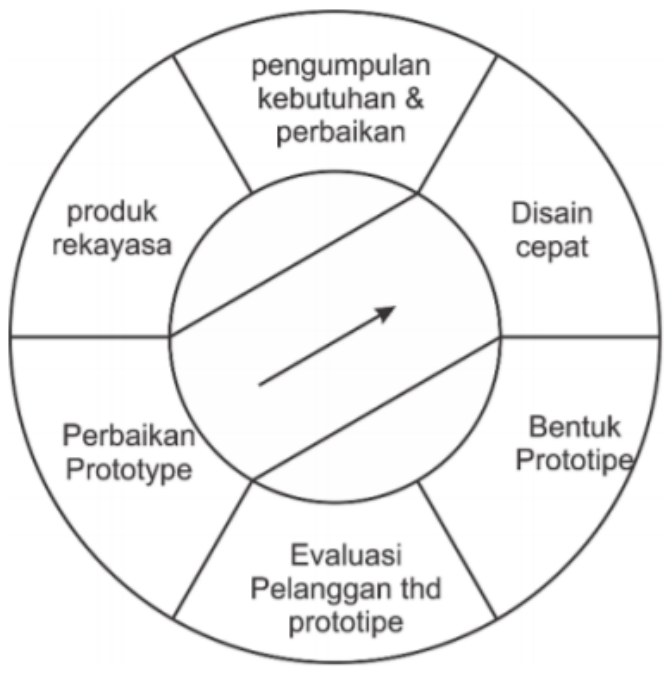

Gambar 1. Tahapan Metode Prototype

1. Pengumpulan kebutuhan, mengidentifikasi seluruh perangkat dan permasalahan kebutuhan dari sistem yang akan dibuat;

2. Desain cepat, proses penterjemahan dari kebutuhan atau keinginan pengguna. Desain yang dibuat berupa rancangan antarmuka yang dapat dengan mudah dimengerti oleh pengguna;

3. Membangun prototype, membangun prototype yang berfokus pada penyajian pelanggan, membuatkan input dan output hasil system;

4. Evaluasi prototype, pelanggan mengevaluasi apakah sistem atau aplikasi yang sudah jadi sudah sesuai dengan yang diharapkan;

5. Perbaikan prototype, merupakan proses perbaikan aplikasi yang telah dibuat sebelumnya. Namun diperbaiki kembali sesuai dengan hasil evaluasi oleh pelanggan sampai semua kebutuhan user terpenuhi;

6. Produk rekayasa, merupakan proses akhir setelah semua kebutuhan dan perbaikan dilakukan atau sudah terpenuhi [15].

Selain metode pengembangan digunakan juga metode pemodelan aplikasi yaitu menggunakan Unified Modeling Language (UML). UML merupakan kumpulan diagram yang memiliki kemampuan untuk 
menggambarkan cetak biru dari sebuah aplikasi. Di dalam penelitian ini digunakan dua jenis diagram yaitu use case diagram yang digunakan untuk menggambarkan fungsional aplikasi yang berkaitan dengan aktor dan use case. Diagram yang kedua yaitu acitivity diagram, diagram ini digunakan untuk menggambarkan aktivitas yang dapat dilakukan oleh aplikasi [16].

\section{HASIL DAN ANALISIS}

Sesuai dengan proses penelitian dan metode pengembangan menggunakan metode prototype maka hasil penelitian dapat dijelaskan sebagai berikut.

\subsection{Kebutuhan Aplikasi}

Kebutuhan informasi pada aplikasi smart cleaning digambarkan dalam bentuk spesifikasi aplikasi. Dimana untuk menggambarkan kebutuhan tersebut digunakan berbagai diagram di dalam notasi unified modeling language. Diagram yang digunakan yaitu use case diagram, activity diagram, dan class diagram. Use case diagram berfungsi untuk menampilkan hubungan-hubungan yang terjadi antara aktor dan case atau fungsional aplikasi. Dalam proses ini ada tiga aktor yang menggunakan sistem yaitu masyarakat, admin, dan petugas. Setiap aktor memiliki case yang berbeda sesuai dengan kebutuhan terhadap sistem. Masyarakat dapat melakukan registrasi terlebih dahulu dan melakukan login untuk mengakses aplikasi tersbut. Setelah itu masyarakat dapat melihat daftar pengaduan dan juga memberikan pengaduan. Pada aktor admin dapat mengelola data pengguna serta melihat daftar pengaduan dan menerima laporan pengaduan masyarakat lalu memverifikasi laporan yang diterima. Ketika admin telah memverifikasi laporan bahwa benar adanya laporan tentang sampah maka petugas melihat laporan tersebut dan mengkonfirmasi laporan dan merubah status pengambilan apakah sudah proses atau belum. Untuk lebih jelas dapat dilihat dari diagram use case pada Gambar 2.

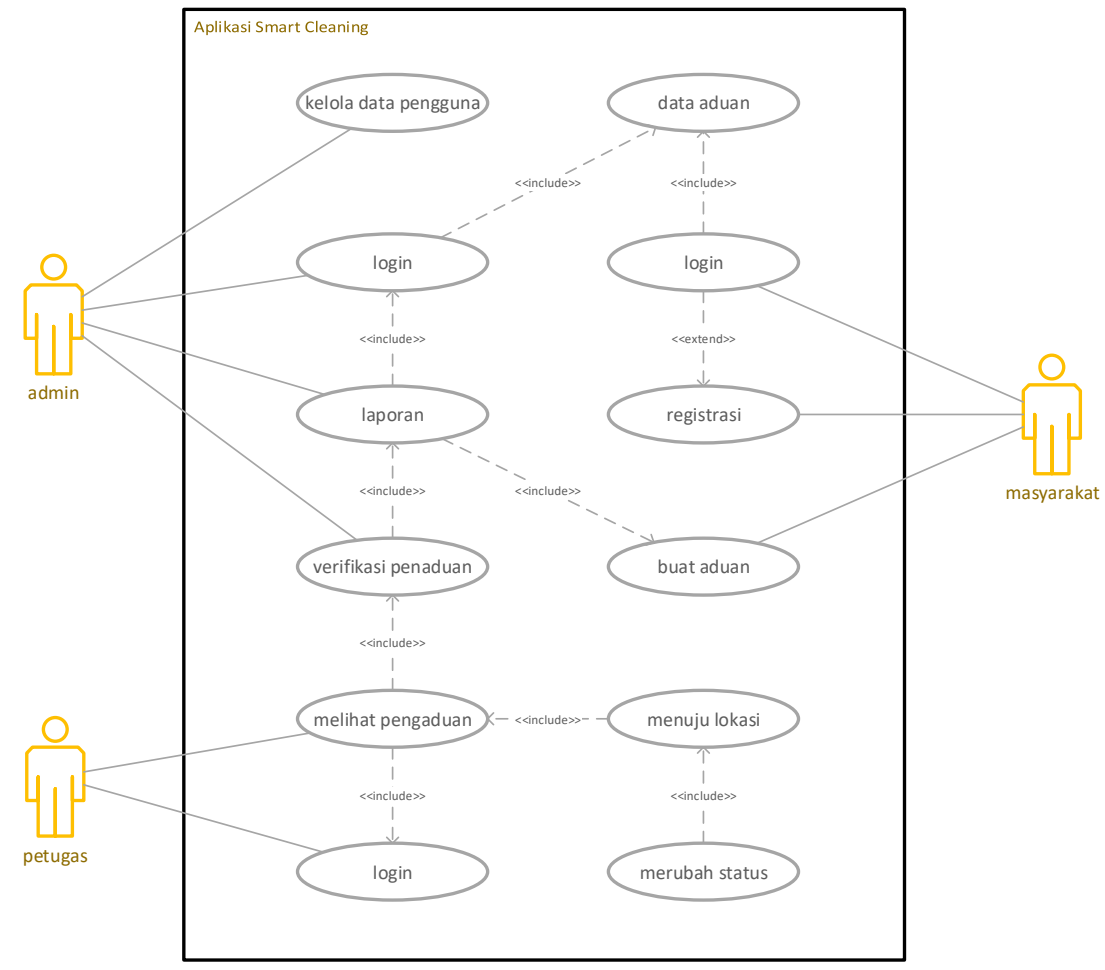

Gambar 2.Use Case Diagram

Setelah mengetahui bagaimana use case diagram seperti pada Gambar 2 maka selanjutnya adalah membuat activity diagram. Sebagaimana diketahui bahwa activity diagram digunakan untuk menggambarkan bagaimana proses atau tahapan pekerjaan dari masing-masing aktor di dalam aplikasi Aplikasi Smart Cleaning Sebagai Pendukung Aplikasi Smart City. Gambar 3 dan Gambar 4 merupakan activity diagram untuk aplikasi tersebut. 


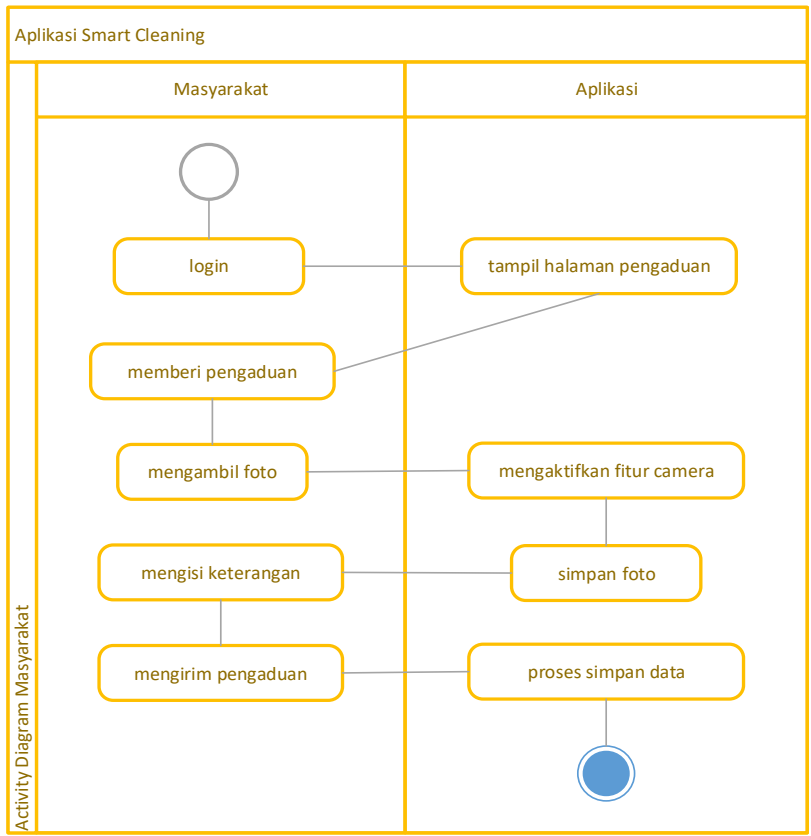

Gambar 3. Activity diagram Masyarakat

Kebutuhan informasi juga digambarkan dalam bentuk activity diagram. Pertama adalah activity diagram masyarakat menjelaskan aliran kerja masyarakat pada aplikasi smart cleaning. Seperti cara melakukan pengaduan dan melihat laporan-laporan masyarakat yang telah melakukan pengaduan yang menggunakan aplikasi tersebut seperti yang diperlihatkan pada activity diagram myarakat pada Gambar 3. Selain activity diagram masyarakat juga terpadat activity diagram administrator. Activity diagram administrator menjelaskan aliran kerja aktor administrator pada aplikasi smart cleaning seperti mengelola data pengguna, melihat daftar pengaduan, dan memverifikasi pengaduan seperti pada Gambar 4.

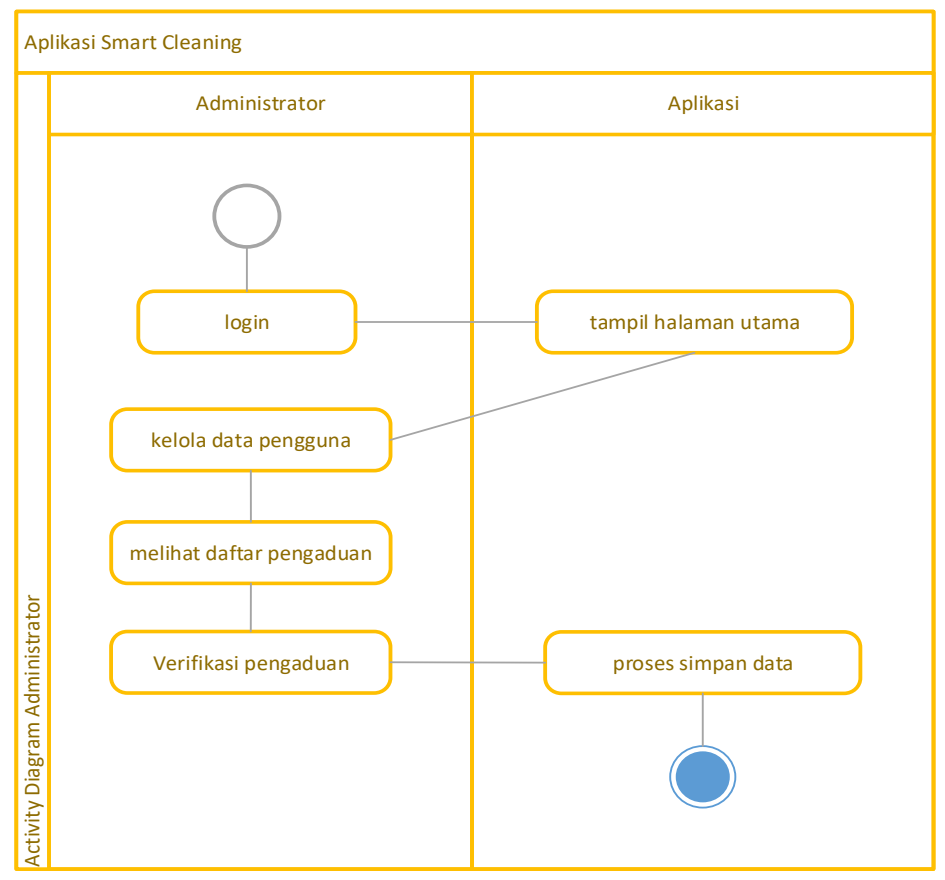

Gambar 4. Activity diagram administrator

Selanjutnya adalah activity diagram petugas. Acitvity diagram ini menjelaskan aliran kerja aktor petugas pada aplikasi smart cleaning seperti melihat laporan pengaduan yang telah divalidasi administrator serta merubah status pengambilan dari sudah diambil atau belum. Gambar 5 merupakan activity diagram untuk pengguna dengan hak akses petugas. 


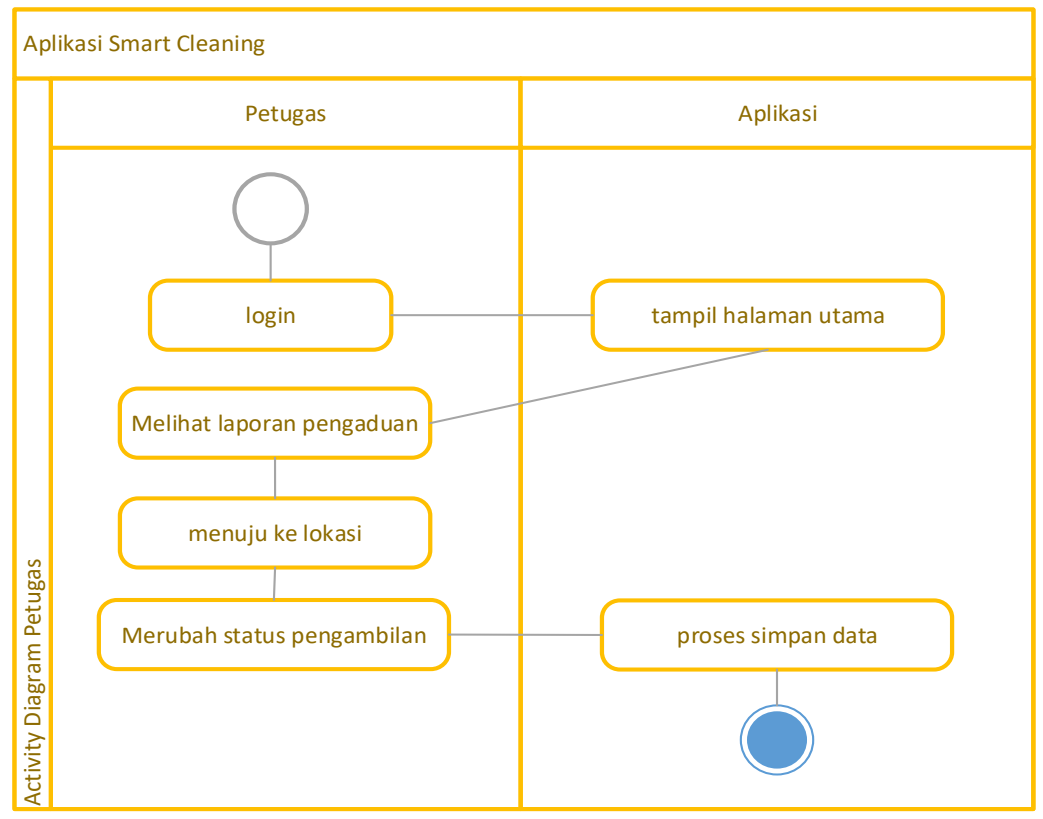

Gambar 5. Activity diagram petugas

\subsection{Hasil Pengembangan Aplikasi}

Setelah mengetahui kebutuhan aplikasi seperti yang telah dijelaskan sebelumnya, maka proses selanjutnya adalah pengembangan aplikasi. Proses pengembangan aplikasi sendiri dilakukan bertahap sesuai prosedur yang ada pada metode pengembangan prototype. Proses pengembangan tersebut meliputi desain awal, pembuatan prototype aplikasi, evaluasi protoytpe aplikasi, perbaikan prototype aplikasi dan release aplikasi. Setelah semua proses pengembagnan tersebut selesai dilakukan maka hasil akhir aplikasi smart cleaning tersebut memiliki tampilan awal seperti pada Gambar 6.

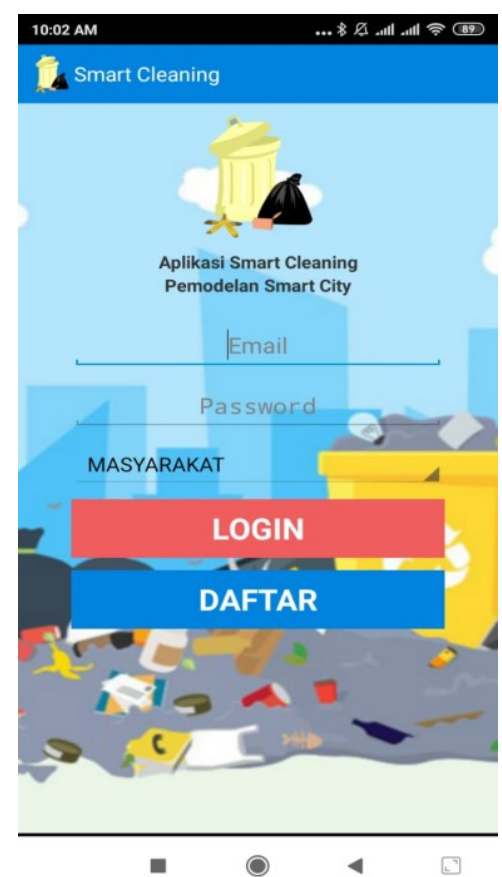

Gambar 6. Tampilan awal aplikasi

Gambar 6 merupakan tampilan awal ketika aplikasi smart cleaning dibuka. Di dalam aplikasi smart cleaning ini terdapat tiga jenis pengguna sesuai dengan kebutuhan aplikasi yang telah diuraikan sebelumnya yaitu (1) administrator; (2) petugas dan (3) masyarakat. Aplikasi smart cleaning ini juga dibuat dalam dua bentuk antarmuka yaitu berbasis mobile dan berbasis web. Antarmuka yang dibuat berbasis mobile digunakan untuk pengguna dengan hak akses masyarakat dan petugas lapangan pengambil sampah. Sedangkan antarmuka 
berbasis web dibuat khusus untuk admnistrator untuk mengelola data, dimana administrator merupakan pihak Dinas Lingkungan Hidup dan Kebersihan Kota Palembang.

Untuk melakukan pelaporan sampah maka pengguna masyarakat haruslah melakukan pendaftaran sebagai pengguna terlebih dahulu. Kondisi tersebut dibuat agar masyarakat yang membuat laporan tidak melakukan spam pada aplikasi. Gambar 7 merupakan proses pendaftaran pengguna untuk masyarakat.
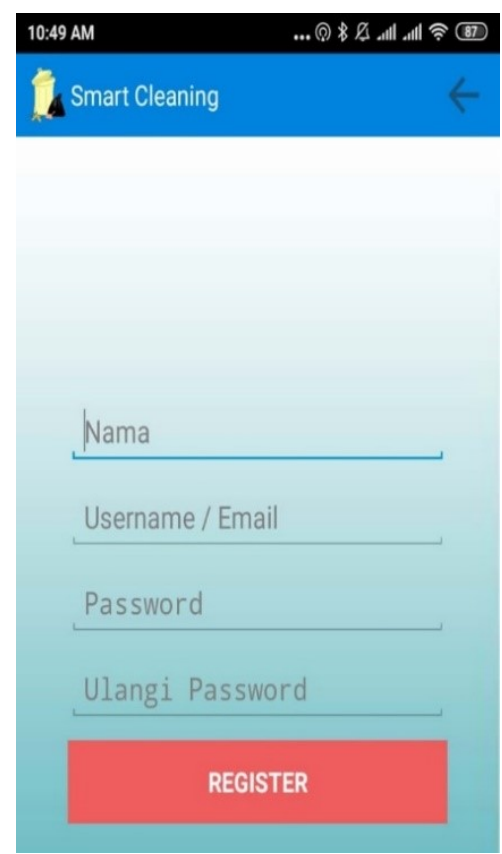

Gambar 7. Pendaftaran pengguna

Setelah melakukan pendaftaran pengguna seperti pada Gambar 7 maka masyarakat dapat melakukan pelaporan seperti pada Gambar 8.

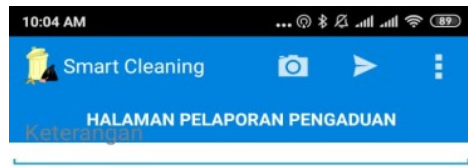

FOTо :

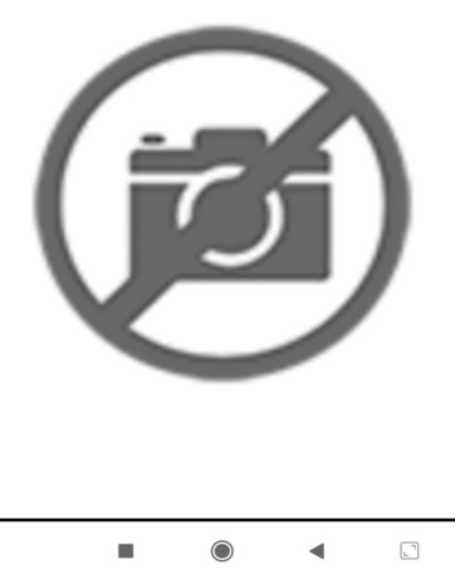

Gambar 8. Form pelaporan masyarakat

Dalam melakukan pelaporan masyarakt dapat memberikan informasi berupa lokasi sampah, gambar sampah dan keterangan atau pesan yang ingin disampaikan. Hasil dari pelaporan masyarakat seperi yang pada Gambar 9. 


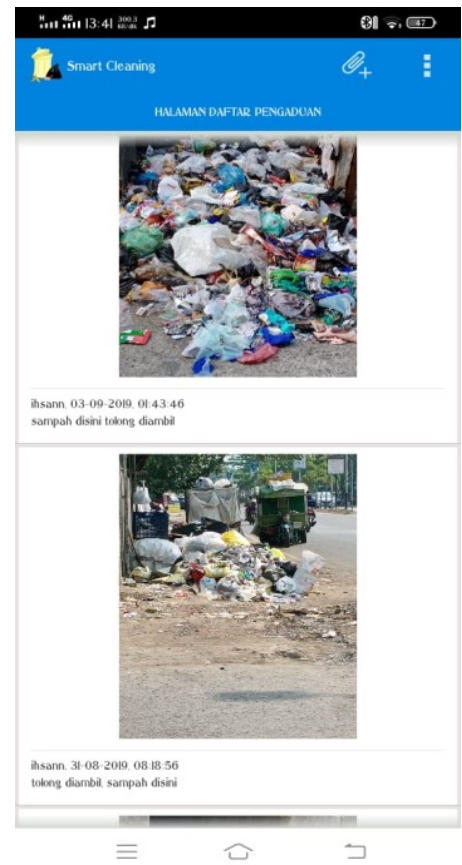

Gambar 9. pelaporan masyarakat

Selanjutnya setelah masyarakat memberikan laporan maka pihak Dinas Lingkungan Hidup dan Kebersihan Kota Palembang dapat melihat laporan dan melakukan validasi atau verifikasi laporan. Jika laporan dianggap benar maka laporan akan diteruskan dan jika tidak maka laporan akan ditolak atau dihapus. Untuk melakukan validasi atau verifikasi tersebut administrator harus melakukan login sebagai pengguna administrator melalui antarmuka berbasis web yang telah disediakan. Setelah sukses melakukan login maka akan ditampilkan halaman utama administrator seperti yang diperlihatkan pada Gambar 10.

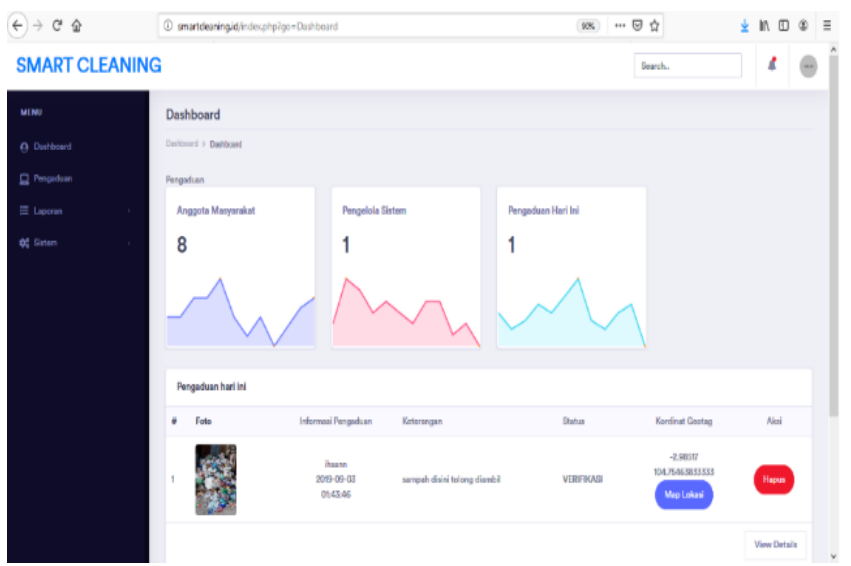

Gambar 10.Halaman utama administrator

Setelah masuk ke halaman administrator seperti yang diperlihatkan pada Gambar 10, maka selanjutnya adminstrator dapat melihat laporan yang masuk. Untuk melihat laporan masuk maka dapat mengklik menu laporan, maka semua laporan yang masuk yang belum diproses akan ditampilkan seperti yang diperlihatkan pada Gambar 11. 


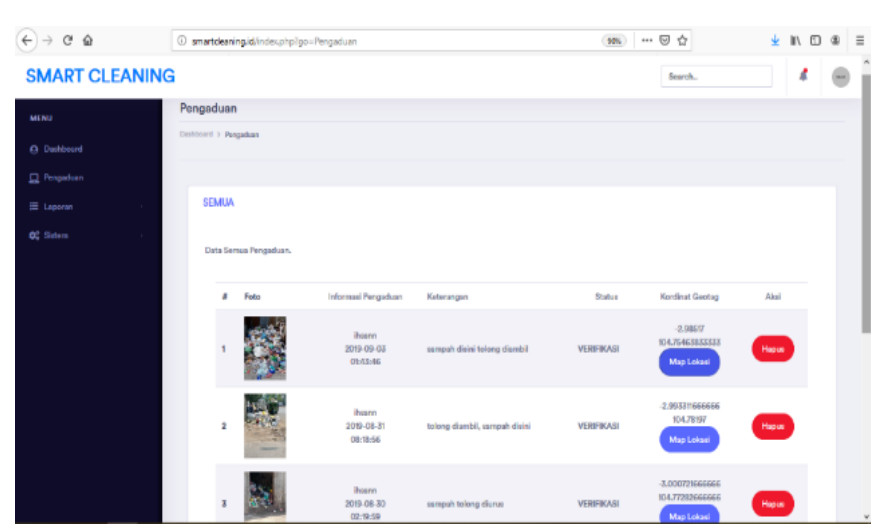

Gambar 11. Pengaduan masyarakat

Selain dari proses laporan yang diberikan masyarakat, administrator juga dapat melihat data statistik atau laporan pengaduan masyarakat dan pengelolaan data pengguna. Untuk melihat data laporan pengaduan dapat dilihat melalui menu laporan. Tampilan laporan pengaduan seperti yang diperlihatkan pada Gambar 12 .

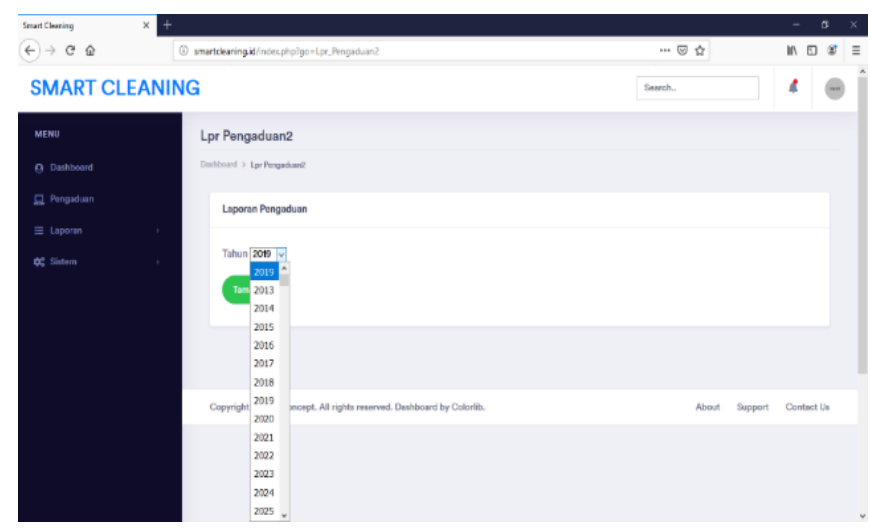

Gambar 12. Laporan pengaduan masyarakat

Administrator aplikasi juga dapat melakukan pengelolaan data pengguna baik yang dimasukkan langsung oleh administrator maupun melakukan pendaftaran melalui aplikasi smart cleaning seperti yang diperlihatkan pada Gambar 13.

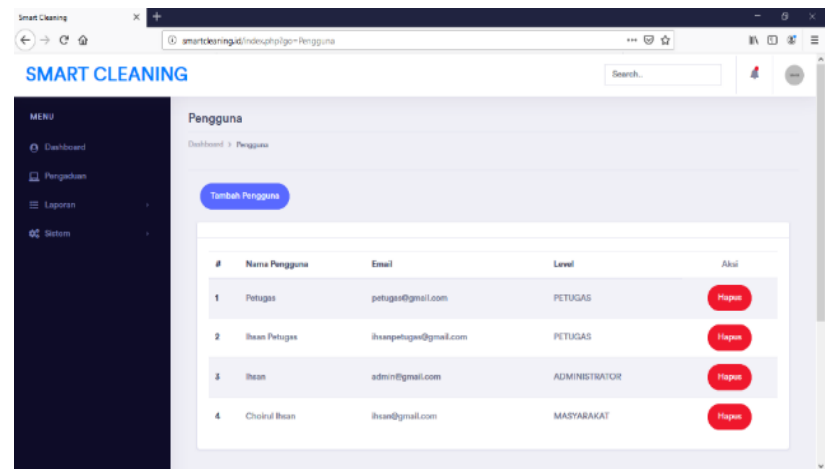

Gambar 13. Data Pengguna

Untuk melakukan tindakan lapangan maka dilakukan oleh petugas pengangkut sampah dalam hal ini merupakan koordinator lapangan seperti sopir truk. Untuk melakukan tindakan maka petugas harus melakukan login pada aplikasi smart cleaning seperti halnya yang dilakukan masyarakat. Setelah selesai login maka petugas dapat melihat pengaduan masyarakat, dimana data yang ditampilkan pada halaman petugas merupakan data yang telah divalidasi dan diverifikasi oleh administrator. Pada Gambar 14 merupakan tampilan dari data data pengaduan yang masuk. 


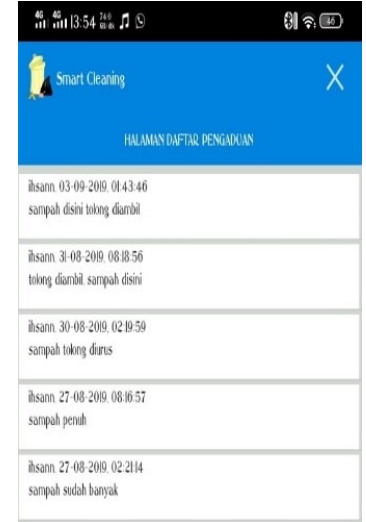

Gambar 14. Laporan pengaduan pada petugas

Untuk melakukan pengambilan sampah sesuai dengan pengaduan masyarakat maka petugas dapat klik pengaduan dan melihat tujuan, maka akan diperlihatkan rute perjalanan seperti pada Gambar 15.

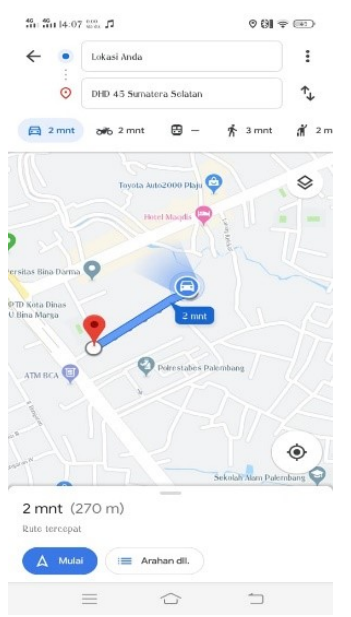

Gambar 15. Rute menuju lokasi

Jika proses pengambilan sampah telah selesai maka petugas dapat merubah status pengaduan menjadi selesai. Jika status menjadi selesai maka data pengaduan akan dihilangkan pada menu petugas. Untuk merubah status tersebut dapat dilakukan pada detail pengaduan dengan cara mengklik menu selesai seperti yang diperlihatkan pada Gambar 16.

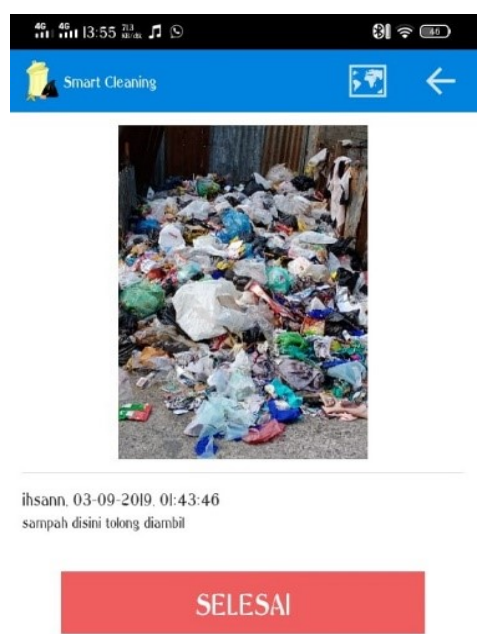

Gambar 16. Perubahan status tindakan 


\section{KESIMPULAN}

Sesuai dengan latar belakang dan tujuan yang telah dikemukakan sebelumnya maka dapat disimpulan bahwa proses pengembangan dengan menggunakan aplikasi menggunakan metode prototype dapat dilakukan sesuai dengan tahapan pengembangan yang terdiri dari pengumpulan kebutuhan, desain cepat, membuat prototype, evaluasi prototype, perbaikan prototype, dan rekayasa produk. Aplikasi yang dihasilkan dalam hal ini aplikasi smart cleaning memiliki fungsi dan fitur dengan fungsi utama pelaporan dari masyarakat, verifikasi oleh admin dan tindakan oleh petugas. Pengguna yang terlibat dapat aplikasi ini terdiri dari masyarakat, administrator dan pengguna sehingga aplikasi dapat dijalankan sesuai keadaan nyata di lapangan dan menjadikan aplikasi berfungsi sebagai jembatan pengaduan masyarakat terkait sampah.

\section{UCAPAN TERIMA KASIH}

Ucapan terima kasih yang setingi-tingginya kami sampaikan kepada "Universitas Bina Darma yang telah membiayai penelitian ini. Terima kasih yang tak terhingga juga disampaikan kepada Tim Redaksi Jurnal Matrik Universitas Bumigora Mataram yang bersedia melakukan review dan mempublikasi artikel ini”.

\section{REFERENSI}

[1] D. Fereshti Nurdiana and C. Mabruroh, "Smartphone: Antara Kebutuhan dan E-Lifestyle," in Seminar Nasional Informatika, 2010.

[2] R. Rahmawati and F. Firman, "Analisis Impelementasi Kebijakan Aplikasi Qlue di Wilayah Jakarta Utara," Aristo, vol. 5, no. 2, pp. 386-404, 2017.

[3] H. K. Siradjuddin and S. Do Abdullah, "Implementasi Prototype Aplikasi E-Lapor Berbasis Jejaring Sosial Untuk Pelayanan Keluhan Pelanggan pada Kantor PDAM,” Jurnal Informatika dan Komputer, vol. 1, no. 1, pp. 27-33, 2018.

[4] E. Faizal, A. Prayitna, and M. Mafmudin, "Sertifikat Hak Cipta-Program Komputer Aplikasi Jogja Mobile City (mCity)," 2019.

[5] F. W. Tholok, S. Santosa, and S. Janamarta, "Studi Ketertarikan Masyarakat Terhadap Penggunaan Aplikasi Tangerang Live (Pendekatan pada Teori Skala SERVQUAL)," Primanomics: Jurnal Ekonomi \& Bisnis, vol. 17, no. 2, pp. 120-129, 2019.

[6] F. Mohamad and F. Tupamahu, "Rancangan Sistem Integrasi Monitoring dan Pelaporan Sampah di Kota Gorontalo Berbasis Android," in SemanTECH (Seminar Nasional Teknologi, Sains dan Humaniora), 2019, vol. 1, no. 1, pp. 50-57.

[7] C. E. W. Utomo and M. Hariadi, "Strategi Pembangunan Smart City dan Tantangannya bagi Masyarakat Kota," Jurnal Strategi dan Bisnis, vol. 4, no. 2, pp. 159-176, 2016.

[8] F. Susanto, "Sistem Informasi Pengolahan Data Pasien pada Puskesmas Abung Pekurun Menggunakan Metode Prototype," Mikrotik: Jurnal Manajemen Informatika, vol. 8, no. 1, pp. 65-73, 2018.

[9] A. Setiadi and F. Alfiah, "Sistem Penjualan Spare Part Toko AJM Motor Menggunakan CI Berbasis Arsitektur MVC," Simetris: Jurnal Teknik Mesin, Elektro dan Ilmu Komputer, vol. 7, no. 2, pp. 575586, 2016.

[10] H. N. Syaddad, "Rancang Bangun Digital Archiving di Perguruan Tinggi Menggunakan Metode Prototype Model Studi Kasus: Universitas Suryakancana,” Media Jurnal Informatika, vol. 9, no. 1, 2018.

[11] D. A. Punkastyo, "Perancangan Aplikasi Tutorial Jurus Dasar Beladiri Cimande Menggunakan Metode Prototype," Jurnal Informatika Universitas Pamulang, vol. 3, no. 2, pp. 87-93, 2018.

[12] A. Zainal, Metodologi Penelitian pada Bidang Ilmu Komputer dan Teknologi Informasi; Konsep, Teknik, dan Aplikasi. Jakarta: Fakultas Ilmu Komputer Universitas Indonesia, 2007.

[13] R. S. Pressman, Software Engineering A Practitioner's Approach, 7th ed. California: McGraw-Hill Education, 2010.

[14] F. Mubarok, H. Harliana, and I. Hadijah, "Perbandingan Antara Metode RUP dan Prototype Dalam Aplikasi Penerimaan Siswa Baru Berbasis Web," Creative Information Technology Journal, vol. 2, no. 2, pp. 114-127, 2015 .

[15] C. Kurniawan and N. F. Wahyuono, "Rancang Bangun Game Pewayangan Anoman Obong Berbasis Android Menggunakan Metode Prototype," 2018.

[16] F. Fatmasari and S. Sauda, "Pemodelan Unified Modeling Language Sistem Informasi Enterprise Resource Planning,” Jurnal Media Informatika Budidarma, vol. 4, no. 2, pp. 429-436, 2020. 
